\title{
ROMAŃSKIE ZABYTKI ARCHITEKTURY SAKRALNEJ INOWROCEAWIA I STRZELNA W ŚWIETLE FOTOGRAFII MEYDENLENDERA Z 1887 ROKU
}

Problematyka inowrocławskiego kościoła pw. Najświętszej Marii Panny (w literaturze przedmiotu równie często spotykamy wezwanie Panny Marii lub pochodne $)^{1}$ oraz rotundy pw. Św. Krzyża (obecne wezwanie św. Prokopa), a także kościoła klasztornego pw. Św. Trójcy i Najświętszej Marii Panny Strzelnie (często określany tylko pierwszym wezwaniem) ${ }^{2}$ i stan zachowania tychże zabytków, zwłaszcza w XIX wieku, wydaje się zagadnieniem wciąż słabo zbadanym. Tymczasem z punktu widzenia konserwatorstwa, historii sztuki czy historii dziejów architektury tychże romańskich budowli analizy dziewiętnastowiecznych źródeł ilustrujących dane zabytki powinny być bardzo wartościowe. Jeśli weźmiemy pod uwagę przywołany wyżej kościół pw. NMP, zrujnowany w toku kolejnych katastrof, zwłaszcza w wyniku pożaru z 1834 roku$^{3}$, to zauważymy jak dużą rolę mo-

* Marcin Danielewski - mgr historii i archeologii, doktorant w Instytucie Historii Uniwersytetu Adama Mickiewicza w Poznaniu. Stypendysta Fundacji UAM w Poznaniu na rok 2012.

${ }^{1}$ W. M., Płaskorzeźby na kościele Panny Maryi w Inowrocławiu, „Przyjaciel Ludu”, 9 (1842) nr 24, s. 185-186; Z. Świechowski, Sztuka romańska w Polsce, Warszawa 1990, s. 43, 44, 54, 170, 171; Tenże, Architektura romańska w Polsce, Warszawa 2000, s. 78; M. Danielewski, Reliefy z murów kościoła Panny Marii w Inowrocławiu, „Roczniki Historyczne”, 77 (2011) s. 7, 10, 11, 32. W dalszej części pracy będę używał zwrotu pw. NMP zarówno w odniesieniu do świątyni w Inowrocławiu, jak i Strzelnie. Trzeba jednak zauważyć, że również zwrot Panny Marii i jego pochodne jest uprawniony.

${ }^{2}$ Z. Świechowski, Strzelno romańskie, Poznań 1998, s. 18, 49-50; D. Karczewski, Dzieje klasztoru norbertanek $w$ Strzelnie do początku XVI wieku, Inowrocław 2001, s. 105-112; K. SulkowskaTuszyńska, Klasztor norbertanek w Strzelnie (XII-XVI wiek). Sacrum i profanum, Toruń 2006, s. 34, 46. W przypadku wezwań świątyń w Inowrocławiu i Strzelnie prezentuję tylko wybraną literaturę przedmiotu.

${ }^{3} \mathrm{Na}$ temat pożaru z 1834 roku, który silnie przyczynił się do zrujnowania kościoła pw. NMP, wielokrotnie informowano w literaturze przedmiotu. W związku z tym prezentuje tylko kilka wybranych tekstów, gdzie znalazły się informacje na temat tej katastrofy, zob. Cz. Sikorski, Reliefy z murów romańskiego kościoła Imienia Najświętszej Marii Panny w Inowrocławiu, „Ziemia Kujawska”, 11 (1995) s. 17; K. Hewner, Kim byt twórca romańskich rzeźb na murach kościoła Imienia 
gą spełniać źródła dziewiętnastowieczne. Pozwalają one bowiem chociażby określić w jakim stopniu inowrocławska świątynia została przebudowana w toku kolejnych renowacji ${ }^{4}$. Podobnie cenne wydają się informacje na temat dziewiętnastowiecznego stanu zachowania zabytków strzeleńskich. Zwłaszcza, jeśli zwrócimy uwagę na fakt, że np. w czasie II wojny światowej dużej dewastacji uległa rotunda pw. Św. Krzyża5. Stąd wszelkie źródła pozwalające odtworzyć dziewiętnastowieczny lub starszy wygląd omawianych zabytków architektury romańskiej wydają się niezwykle wartościowe. Jednocześnie materiały te $\mathrm{z}$ pewnością ułatwiają działalność konserwatorską prowadzoną przy budowlach sakralnych Inowrocławia oraz Strzelna. Szczególne miejsce wśród źródeł z XIX wieku zdają się zajmować fotografie. Tego rodzaju dziewiętnastowieczne materiały źródłowe są niezbyt liczne w porównaniu do tej samej kategorii źródeł pochodzących z XX wieku. Jednak z punktu widzenia historyka sztuki, konserwatora czy historyka wartość poznawcza zdjęć ilustrujących zabytki architektury jest trudna do przecenienia.

Inowrocławski kościół pw. NMP, strzeleńska rotunda pw. Św. Krzyża i klasztorny kościół pw. Św. Trójcy i NMP wydają się na tle powyższych wstępnych rozważań przykładami niezwykle interesującymi. Zabytki te zostały bowiem udokumentowane w postaci dziewiętnastowiecznych fotografii w ramach zbioru jednego autora. Wspomniany wyżej materiał fotograficzny wykonał w technice fotogrametrii ${ }^{6} \mathrm{~W} 1887$ roku radca rejencyjny Meydenlender ${ }^{7}$. W ramach tego zbioru

Najświętszej Maryi Panny w Inowrocławiu?, „Ziemia Kujawska”, 13 (1998) s. 151; Z. Sroka, Zagrożenia i lęki średniowiecznych inowrocławian (problematyka plaskorzeźb i rytów na kościele pod wezwaniem Imienia Najświętszej Marii Panny w Inowrocławiu), „Materiały do Dziejów Kultury i Sztuki Bydgoszczy i Regionu”, 6 (2001) s. 110.

${ }^{4}$ Takie analizy, wykorzystując tytułowe fotografie Meydenlendera i porównując je z obecnym stanem zachowania inowrocławskiego kościoła pw. NMP, przeprowadziłem w 2011 roku, zob. Danielewski, Reliefy z murów, s. 28, 30, 31, 32, 33; Wówczas też wytknąłem nieuzasadnioną ingerencję konserwatorską (doszło do niej wiosną 2011 roku) w strukturę ściany północnej świątyni, związaną z wtórnym wstawieniem dwóch ciosów z reliefami. Niestety, decyzja ta była chybiona, co potwierdziły źródła dziewiętnastowieczne (fotografie oraz opisy kościoła), zob. Tamże, s. 29, 33.

${ }^{5}$ Świechowski, Strzelno, s. 56; Tenże, Katalog architektury romańskiej w Polsce, Warszawa 2009, s. 487; Choć trzeba zauważyć, że również wcześniej zabytek ten ulegał częstym uszkodzeniom.

${ }^{6}$ Słów kilka należy również poświęcić samej fotogrametrii. Mianowicie, pierwszą fotograficzną kamerę pomiarową do wykorzystania w technice fotogrametrii naziemnej opracował w 1859 roku Aime Laussedat. Trzeba również dodać, że dość szybko fotogrametrię naziemną zaczęto stosować na terenie Niemiec. Już w 1859 roku Albrecht Meydenbauer zastosował ją w odniesieniu do katedry w Wetzlar. Wkrótce też w 1885 roku w Prusach powstał Królewski Instytut Fotogrametrii, którego dyrektorem został A. Meydenbauer. W ramach jego działalności do 1920 roku zarejestrowano techniką fotogrametrii 2600 obiektów architektonicznych, zob. J. Butowitt, R. Kaczyński, Fotogrametria, Warszawa 2010, s. 13-14.

${ }^{7}$ Bliższe informacje na temat datacji tego zbioru znajdują się w następującym tekście: M. Mrugalska-Banaszak, Jeden dzień z Ratuszem w tle. Poznań 13 sierpnia 1887, Poznań 2004. W kwestii datacji tychże fotografii konsultowałem się również z autorką wymienionej wyżej ksiązki. Por. J. Skuratowicz, Ratusz poznański, Poznań 2003, s. 31. Autor w wymienionej pracy także zaprezento- 
możemy wyróżnić trzy jego części składowe. Do pierwszej należy zaliczyć fotografie ilustrujące przede wszystkim Ratusz, a w dalszej kolejności kilka innych poznańskich budowli. Ten materiał fotograficzny został wykonany 13 sierpnia $1887 \mathrm{roku}^{8}$. Szczegółowo i wyczerpująco fotografie te w swoich publikacjach omówiła Magdalena Mrugalska-Banaszak ${ }^{9}$ i ten zbiór nie będzie obiektem moich dalszych rozważań. Druga część zestawu w liczbie 9 fotografii przedstawia rotundę pw. Św. Krzyża oraz klasztorny kościół pw. Św. Trójcy i NMP w Strzelnie. Odpowiednio 6 zdjęć prezentuje dziewiętnastowieczny wygląd pierwszego z wyżej wymienionych romańskich zabytków. Architektura zabudowań kościoła klasztornego ze Strzelna została przedstawione na 3 fotografiach. Trzecia składowa materiału fotograficznego Meydenlendera ilustruje ruinę dziewiętnastowiecznego kościoła pw. NMP. W przypadku tej części zbioru mamy do czynienia z 6 fotografiami. Właśnie te dwie części zestawu zdjęć odnoszące się do Inowrocławia oraz Strzelna będą obiektem moich dalszych rozważań. Osobno i na uboczu należy także wspomnieć o 4 fotografiach ilustrujących detale architektoniczne Inowrocławia (reliefy kamiennych głów) i Strzelna (dwa tympanony oraz jeden relief). Zdjęcia te znajdują się $\mathrm{w}$ jednym $\mathrm{z}$ dwóch omawianych dalej zbiorów materiału fotograficznego Meydenlendera. Z tym że za autora tych zdjęć trudno uznać wspomnianego wyżej radcę rejencyjnego ${ }^{10}$. W związku $z$ tym fotografie te nie będą obiektem moich głównych rozważań.

Nim jednak przejdę do szczegółowego omówienia materiału fotograficznego należy nieco miejsca poświęcić jego autorowi. Niestety, w tej kwestii nie wiele wiadomo. Z informacji zawartych w „Kurierze Poznańskim” wynika, że Meydenlender był radcą rejencyjnym. Jego pobytu na Kujawach i w Wielkopolsce nie można uznać za całkowicie przypadkowy. Mamy w tym przypadku do czynienia z szerszą akcją konserwatorską i zarazem docenieniem zabytków Poznania, Inowrocławia i Strzelna. Co interesujące oraz warte podkreślenia, inicjatywa ta wyszła z Berlina. Już 9 sierpnia 1887 roku z Berlina do Poznania przybyli radca rejencyjny dr Jordan i konserwator pomników tajny radca rejencyjny Persius mający ocenić stan konserwatorski tamtejszych zabytków ${ }^{11}$. W związku z tym przyjazd Meydenlendera do Poznania 12 sierpnia 1887 roku należy widzieć jako etap fotograficznego udokumentowania zabytków. Celem finalnym całego przedsięwzięcia miało być przyszłe odrestaurowanie budowli Poznania, Inowrocławia i Strzelna. Warto w tym miejscu dodać, że radca rejencyjny został wysłany do prowincji

wał jedno ze zdjęć Ratusza wykonane przez Meydenlendera, podając również jego datację roczną 1887. Jednocześnie Jan Skuratowicz uznał, iż autor tej i kilku innych fotografii jest nieznany.

${ }^{8}$ „Kurier Poznański”, r. 16, nr 186 (17 sierpień 1887 rok). Por. Mrugalska-Banaszak, Od Brauna i Hogenberga do radcy rejencyjnego Meydenlendera. Wizerunki ratusza z 1618-1887, „Kronika Miasta Poznania", 2 (2004) s. 250; Taż, Jeden dzień z Ratuszem.

${ }^{9}$ Mrugalska-Banaszak, Od Brauna i Hogenberga, s. 250-258; Taż, Jeden dzień z Ratuszem.

${ }^{10}$ Do problematyki tej wrócę jeszcze omawiając kolekcję fotografii Meydenlendera zgromadzoną w Muzeum Miasta Poznania. Patrz przyp. 20.

${ }^{11}$ „Kurier Poznański” r. 16, nr 182 (11 sierpień 1887 rok). Por. Mrugalska-Banaszak, Jeden dzień z Ratuszem. 
poznańskiej z inicjatywy ministra kultury ${ }^{12}$. Z czasem, jeszcze $w$ okresie rządów niemieckich w rejencji bydgoskiej i poznańskiej, podjęto działania konserwatorskie zmierzające do odbudowania kościoła pw. NMP w Inowrocławiu i odrestaurowania rotundy pw. Św. Krzyża oraz kościoła klasztornego pw. Św. Trójcy i NMP w Strzelnie ${ }^{13}$. Niestety, nic więcej na temat samego Meydenlendera nie wiadomo. Może poza tym, iż nieobca była mu technika fotogrametrii ${ }^{14}$, co zresztą potwierdzają wykonane przez radcę zdjęcia.

Osobnym zagadnieniem są losy tychże fotografii Meydenlendera. Wspominałem już wyżej, że materiał fotograficzny dotyczący Ratusza i innych zabytków poznańskich, został wykonany 13 sierpnia $1887 \mathrm{roku}^{15}$. Jednocześnie na podstawie „Kuriera Poznańskiego” można wnioskować, iż Meydenlender opuścił miasto Poznań dzień później ${ }^{16}$. Niestety, brakuje wiadomości na temat dnia, w którym zostały wykonane kolejne fotografie oraz w jakiej kolejności radca rejencyjny odwiedzał Inowrocław i Strzelno. W tym przypadku pozostają jedynie spekulacje. Z Wielkopolski na Kujawy można było dotrzeć dwoma drogami. Jedna biegła przez Gniezno, Trzemeszno oraz Kwieciszewo i dalej Strzelno. Druga zaś droga zlokalizowana bardziej na północ, kierowała się przez Pałuki i Załachowo lub Pakość m.in. w stronę Inowrocławia. Istnienie tych dwóch głównych traktów, użytkowanych w zasadzie już od okresu średniowiecza ${ }^{17}$, powoduje, że nie ma możliwości aby obecnie określić, który z ośrodków - Inowrocław czy Strzelno

${ }^{12}$ „Kurier Poznański, r. 16, nr 186 (17 sierpień 1887 rok).

${ }^{13}$ Kościół pw. NMP w Inowrocławiu został zrekonstruowany w latach 1900-1902. Podczas gdy rotundę pw. Św. Krzyża oraz kościół Św. Trójcy i NMP odrestaurowywano m.in. w 1892 roku, zob. Cz. Sikorski, Kościół Imienia Najświętszej Maryi Panny w Inowrocławiu, Inowrocław 1991, s. 13; K. Śmigiel, Biskup Antoni Laubitz 1861-1939, Gniezno 1994, s. 64; Świechowski, Strzelno, s. 56; Tenże, Architektura romańska, s. 79, 234, 238; Tenże, Katalog architektury, s. 122, 464, 486-487. Oczywiście, zaprezentowana literatura przedmiotu dotycząca kwestii renowacji omawianych przeze mnie zabytków architektury romańskiej ma charakter selektywny. Najpóźniej renowacji został poddany poznański Ratusz, który nie jest głównym tematem moich rozważań. Obiekt ten odrestaurowano w latach 1910-1913, zob. Mrugalska-Banaszak, Jeden dzień z Ratuszem; Skuratowicz, Ratusz poznański 3.37.

${ }^{14}$ „Kurier Poznański, r. 16, nr 186 (17 sierpień 1887 rok). W tejże prasie sugerowano nawet, iż to właśnie Meydenlender wynalazł technikę fotogrametrii, co nie było oczywiście prawdą. Por. Mrugalska-Banaszak, Jeden dzień z Ratuszem.

${ }^{15}$ Patrz przyp. 7 i 8.

${ }^{16}$ „Kurier Poznański, r. 16, nr 186 (17 sierpień 1887 rok); Mrugalska-Banaszak, Jeden dzień $z$ Ratuszem.

${ }^{17}$ S. Weyman, Cta i drogi handlowe w Polsce Piastowskiej, Poznań 1938, s. 105, 108 mapa; tenże, Ze studiów nad zagadnieniem dróg w Wielkopolsce od X do XVIII w., „Przegląd Zachodni” IX (1953), nr 6-8, s. 214-215. Warto zauważyć, iż również obecnie są to dwie drogi prowadzące z Wielkopolski na Kujaw na osi zachód-wschód. Chociaż ich przebieg jest nieco inny niż w średniowieczu. Spostrzeżenie to dotyczy zwłaszcza szlaku północnego biegnącego przez Pałuki. Obecnie droga ta omija Załachowo, o którym wspominał Stefan Weyman, a sięga Żnina, Barcina czy Pakości. W tym miejscu trzeba dodać, że wymieniony wyżej historyk Załachowo wymienione w dokumencie z 1252 roku, zob. Codex diplomaticus Prussicus, t. I, wyd. J. Voigt, Königsberg 1836, nr 90, identyfikował z Żelechowem. Oczywiście, zapis z dokumentu - Zalacouo wskazuje wyraźnie na Załachowo, co zresztą zauważano już w dotychczasowej literaturze przedmiotu, zob. Z. Guldon, J. Powierski, Po- 
był pierwszym na szlaku podróży Meydenlendera. Można jedynie snuć domysły. Mianowicie, szlak biegnący przez Gniezno, Trzemeszno, Kwieciszewo miał większe znaczenie niż droga północna z Załachowem lub Pakością. Stąd można sądzić, iż Meydenlender kierował się z Poznania na Kujawy drogą południową. Należałoby zatem uznać, że radca rejencyjny wpierw odwiedził Strzelno, wykonując fotografie tamtejszych zabytków architektury romańskiej ${ }^{18}$. Niestety, jest to tylko hipoteza dla której brakuje szerszej podstawy źródłowej. Trudno więc opierając się na niej jednoznacznie rozstrzygnąć, która z miejscowości - Inowrocław czy Strzelno znalazła się pierwsza na szlaku podróży Meydenlendera. Zwłaszcza, że wykorzystywanie szlaku północnego prowadzącego przez Pakość na Kujawy jest również potwierdzone w opisach innych dziewiętnastowiecznych podróży ${ }^{19}$. Bez względu na to którą z omawianych wyżej dróg wybrał, musiał Meydenlender dotrzeć na Kujawy w ciągu jednego góra dwóch dni. Radca rejencyjny po wykonaniu dokumentacji z pewnością powrócił do Berlina. Dalsze losy fotografii są dość złożone. Potwierdza to chociażby fakt, iż dwa zbiory częściowo powtarzających się zdjęć znajdują się obecnie w dwóch różnych placówkach naukowych Poznania. Pierwsza kolekcja składająca się w sumie z 28 fotografii oprawionych w album, jest przechowywana w Muzeum Miasta Poznania. Z tym, że na ten zestaw składają się również inne zdjęcia, przynajmniej 4, których autorstwo trudno przypisać Meydenlenderowi, w związku z czym nie są one obiektem moich ana${ }_{1 i z}{ }^{20}$. Wiadomo, iż cała kolekcja fotografii znajdowała się wcześniej w zbiorze

działy administracyjne Kujaw i Ziemi Dobrzyńskiej w XIII-XIV wieku, Warszawa 1974, s. 89, 91, 180; B. Śliwiński, Pogranicze kujawsko-pomorskie w XII-XIII wieku, Warszawa 1989, s. 139.

${ }^{18}$ Do takiej kolejności odwiedzanych miejsc przez Meydenlendera skłaniała się również Mrugalska-Banaszak, Jeden dzień z Ratuszem.

${ }^{19} \mathrm{~J}$. Łepkowski, O zabytkach Kruszwicy, Gniezna i Krakowa oraz Trzemeszna, Rogoźna, Kcyni, Dobieszewa, Gołańczy, Żnina, Gąsawy, Pakości, Kościelca, Inowrocławia, Strzelna i Mogilna, Kraków 1866, s. 117-188. Podróż trwająca trzy dnia miała rozpocząć się w Rogoźnie i przebiegać zgodnie z wymienionymi w tytule pracy miejscowościami. Wyraźnie więc z tego wynika, iż Józef Łepkowski dotarł na Kujawy drogą północną prowadzącą przez Pakość.

${ }^{20}$ Mam w tym przypadku na uwadze 4 fotografie przedstawiające detale architektoniczne Strzelna i Inowrocławia. Pierwsze trzy zdjęcia ilustrują kolejno kamienny cios z reliefem krzyża greckiego z beleczkami, tympanon fundacyjny zniszczony w 1945 roku i tympanon fundacyjny wtórnie wmontowany w gotycki portal kaplicy św. Barbary. Wszystkie te fotografie są podpisane jako przedstawiające zabytki Strzelna. Por. Muzeum Miasta Poznania (dalej cyt. MMP) 14/1, 2, 3. Dodatkowo czwarte zdjęcie prezentuje kamienne reliefy głów wraz z portalem północnym kościoła pw. NMP w Inowrocławiu, zob. MMP 52/1. Numerację podaję zgodnie z tą nadaną w omawianym albumie znajdującym się w Muzeum Miasta Poznania. Spieszę zauważyć, że jakość tych 4 fotografii znacznie odstaje od pozostałych zdjęć. Jednocześnie materiał fotograficzny przypisywany Meydenlenderowi charakteryzuje się stałym rozmiarem odbitek, zob. Mrugalska-Banaszak, Jeden dzień $z$ Ratuszem. Tymczasem te 4 fotografie detali architektonicznych Inowrocławia i Strzelna są niewielkie w swoim rozmiarze. Dodatkowo również ich jakość, zwłaszcza zdjęcia ilustrującego kamienne reliefy głów (MMP 52/1) odstaje od materiału fotograficznego przypisywanego Meydenlenderowi. Nie jestem więc skłonny, aby uznać te 4 fotografie za część zbioru mającego być autorstwem radcy rejencyjnego. Trudno nawet stwierdzić czy wykonała je jedna osoba. Jednak mimo to na uboczu głównych rozważań trzeba poczynić 3 spostrzeżenia. Mianowicie, fotografia przestawia- 
Królewskiej Biblioteki Regencji w Poznaniu. Stamtąd trafiły one do Głównej Biblioteki Województwa Poznańskiego. Dopiero z tej ostatniej instytucji po II wojnie światowej fotografie zostały złożone w Muzeum Miasta Poznania, gdzie znajdują się do teraz ${ }^{21}$. Zupełnie inne losy były udziałem drugiego ze zbiorów składającego się z 16 zdjęć, a który znajduje się w Pracowni Ikonograficznej Oddziału Zbiorów Specjalnych Biblioteki Uniwersyteckiej w Poznaniu. Na odwrocie fotografii widoczna jest pieczęć urzędu fotogrametrycznego z Berlina z następującym podpisem: Kgl. Pr. Messbild - Austalt Berlin W. 56. Schinkelpl. 6. i z datą roczną 1906. Oprócz tego znajduje się tam kilka różnych numeracji nadawanych zdjęciom tej kolekcji wraz z zmianami jej lokalizacji22. Wspomniana wyżej pieczęć wskazuje na fakt, że w 1906 roku fotografie Meydenlendera były jeszcze w stolicy ówczesnej Rzeszy Niemieckiej. Następnie, trudno określić kiedy dokładnie, zdjęcia te trafiły do poznańskiej Biblioteki Cesarza Wilhelma - Kaiser-Wilhelm-Bibliothek. Z pewnością jednak znajdowały się one w tej instytucji, co potwierdzają kolejne opisy z odwrotu materiału fotograficznego. Wydaje się, że kolejno, wraz z powstaniem Biblioteki Uniwersyteckiej w Poznaniu, zbiory dawnej Kaiser-Wilhelm-Bibliothek, w tym kolekcja fotografii Meydenlendera, znalazły się w pierwszej z wyżej wymienionych instytucji ${ }^{23}$. Trzeba jednak podkreślić,

jąca zniszczony tympanon fundacyjny w 1945 roku (MMP 14/2), nie mogła zostać wykonana po 1892 roku. Zgodnie z informacjami Zygmunta Świechowskiego tympanon ten znajdował się w ścianie jednej z przybudówek rotundy tylko do renowacji tego zabytku w 1892 roku. Wówczas to tympanon został przeniesiony do wnętrza rotundy pw. Św. Krzyża, zob. Świechowski, Architektura romańska, s. 239; tenże, Katalog architektury, s. 489. Wydaje się więc, że górną granicą wykonania fotografii ilustrującej omawiany tympanon, jest rok 1892. Również zdjęcie przedstawiające kamienne reliefy głów (MMP 52/1) można orientacyjnie datować. Na fotografii widzimy bowiem, że kościół pw. NMP znajdował się wówczas w ruinie. Na tej podstawie należy wnioskować, iż wykonanie zdjęcia musiało nastąpić przed latami 1900-1902, kiedy to świątynia została poddana renowacji. Patrz przyp. 13. Ostatnie spostrzeżenie dotyczy fotografii przedstawiającej kamienny cios z reliefem krzyża greckiego z beleczkami, MMP 14/1. Uwaga ta nie odnosi się jednak do datacji. Mianowicie, identycznie wyryty znak w kamieniu (ma nawet takie samo odbicie), obecnie znajduje się w murze apsydy kościoła pw. NMP w Inowrocławiu, zob. M. Danielewski, Reliefy z murów, s. 11, 30. Nie jest to miejsce aby szczegółowo wyjaśniać tę kwestię, ale wydaje się, iż do problemu tego należałoby w przyszłości jeszcze powrócić.

${ }^{21}$ Mrugalska-Banaszak, Jeden dzień z Ratuszem. Z fotografiami tymi dzięki uprzejmości kierownika Muzeum Miasta Poznania, M. Mrugalskiej-Banaszak, po raz pierwszy miałem okazję zapoznać się w marcu 2011 roku.

${ }^{22}$ Dalej w tekście zachowuję numerację zdjęć nadaną prawdopodobnie w Kaiser-Wilhelm-Bibliothek i jej się też trzymam. W związku z tym fotografie wykonane przez Meydenlendera, a znajdujące się w Pracowni Ikonograficznej Oddziału Zbiorów Specjalnych Biblioteki Uniwersyteckiej w Poznaniu (dalej cyt.: PIOZS BUPń), będę dalej oznaczał odpowiednim skrótem i numeracją z Kaiser-Wilhelm-Bibliothek. Trzeba jednak dodać, iż na odwrocie fotografii znajdziemy również inne numeracje, np. błędnego inwentarza. Informacje na ten temat uzyskałem od Jakuba Skuteckiego pracownika Pracowni Ikonograficznej Oddziału Zbiorów Specjalnych Biblioteki Uniwersyteckiej w Poznaniu.

${ }^{23} \mathrm{Z}$ fotografiami Meydenlendera zgromadzonymi w Bibliotece Uniwersyteckiej w Poznaniu, miałem okazję zapoznać się po raz pierwszy w styczniu 2011 roku dzięki uprzejmości Jakuba Skuteckiego. Por. Danielewski, Reliefy z murów, przyp. 30 s. 19. 
iż zestaw zdjęć wykonanych przez radcę rejencyjnego, a zgromadzony w Bibliotece Uniwersyteckiej, nie zawiera materiału fotograficznego przedstawiającego poznański Ratusz.

Pomimo dużej wartości poznawczej fotografie Meydenlendera w odniesieniu do zabytków Inowrocławia oraz Strzelna były w literaturze przedmiotu wykorzystywane rzadko i zwykle bez znajomości ich autora czy czasu powstania ${ }^{24}$. Fakt ten musi dziwić, ale jednocześnie może też sugerować, iż odbitki niektórych zdjęć Meydenlendera znajdują się w innych zbiorach archiwalnych, z których to autorzy kolejnych prac mogli ewentualnie korzystać ${ }^{25}$. Obecnie wiadomo jednak, iż omawiane fotografie zgromadzono w zbiorach Muzeum Miasta Poznania oraz Biblioteki Uniwersyteckiej. Odnosząc się do problematyki kościoła pw. NMP w Inowrocławiu trzeba zauważyć, że naukowcem który wsparł się w swoich badaniach fotografiami Meydenlendera był Jerzy Frycz. Autor podejmując się w 1982 roku rozważań nad dziejami omawianej świątyni, sięgnął do wielu dziewiętnastowiecznych źródeł, także do materiału fotograficznego. W związku z tym w pracy J. Frycza znajdują się reprodukcje 3 lub 4 z 6 fotografii Meydenlendera odnoszących się do inowrocławskiego kościoła. Wszystkie one zostały wykadrowane i podpisane jako wykonane około 1890 roku $^{26}$. Nie ma wątpliwości, iż są to zdjęcia zrobione przez radcę rejencyjnego. Wydaje się jednak, że toruński naukowiec

${ }^{24}$ Wyjątkiem na tym tle jest publikacja M. Mrugalskiej-Banaszak, ale akurat ta praca dotyczy Poznania, a precyzyjniej ujmując, problemu tamtejszego Ratusza, zob. Mrugalska-Banaszak, Jeden dzień z Ratuszem.

${ }^{25}$ Autorzy większości dalej przywoływanych prac, w których znalazły się niektóre z fotografii Meydenlendera, zwykle nie podawali ze zbiorów jakiego archiwum, biblioteki, muzeum czy opracowania pochodzą reprodukcje zdjęć. Patrz przyp. 26, 32, 37.

${ }^{26}$ J. Frycz, Architektura i sztuka Inowrocławia, w: Dzieje Inowrocławia, t. II, Warszawa 1982, ryc. 7 s. 425 , ryc. 8 s. 426 , ryc. 16 s. 442 . Najprawdopodobniej są to odpowiednio następujące zdjęcia, zob. PIOZS BUPń, nr 519, 522, 523. W publikacji J. Frycza znajdujemy jeszcze jedną fotografię przedstawiająca wnętrze części prezbiterium kościoła, zob. Frycz, Architektura i sztuka, ryc. 10 s. 428. Pozostaje jednak pytanie czy jest to kolejne zdjęcie przedstawiające ruinę kościoła pw. NMP w Inowrocławiu? W tym przypadku nie można by uznać tej fotografii za część zbioru Meydenlendera. W żadnym bowiem z dwóch zestawów tych zdjęć znajdujących się w Poznaniu, nie ma takiej fotografii. Nie wykluczam jednak, że omawiane źródło to wykadrowana i mająca przedstawić tylko pewien wycinek prezbiterium, fotografia Meydenlendera, oryginalnie prezentująca całe prezbiterium. Por. PIOZS BUPń, nr 524. Kwestii tej jednak nie sposób jednoznacznie rozwiązać. Chociaż charakterystyczne uszkodzenia na fotografii Meydenlendera znajdujemy również w reprodukcji J. Frycza. Osobiście skłaniam się ku poglądowi, iż mamy do czynienia z tym samym zdjęciem. Z tym, że dla potrzeb tekstu toruńskiego historyka sztuki została tak wykadrowana, aby zaprezentować tylko wycinek prezbiterium. Trzeba także zauważyć, iż fotografia całego prezbiterium zamieszczona w pracy J. Frycza różni się od oryginalnego zdjęcia wykonanego przez Meydenlendera, zob. J. Frycz, Architektura i sztuka, ryc. 9 s. 427. Można jedynie zastanawiać się czy wykadrowanie fotografii doprowadziło do takich zniekształceń czy też rzeczywiście mamy do czynienia z nowym materiałem fotograficznym? Mimo iż już wcześniej zauważyłem tę różnicę to jednak ostatecznie dopiero teraz stwierdzam, że kadrowanie zdjęcia w pracy J. Frycza wywołało taki niepożądany efekt. Skłaniam się więc ku temu, iż obie fotografie: opublikowana przez toruńskiego historyka sztuki (Frycz, Architektura i sztuka, ryc. 9 s. 427) oraz ta ze zbioru Meydenlendera (PIOZS BUPń, nr 524), są jednak tożsame. 
nie korzystał w tym przypadku z poznańskich zbiorów fotografii Meydenlendera, nie informował on $\mathrm{w}$ sposób przejrzysty o pochodzeniu zdjęćc ${ }^{27}$. Jednocześnie można sądzić, iż J. Frycz wyzyskując materiał fotograficzny zgromadzony w Bibliotece Uniwersyteckiej lub w Muzeum Miasta Poznania, nie pominąłby informacji o kolejnych dwóch zdjęciach radcy rejencyjnego, ilustrujących inowrocławski kościół. Jednocześnie mało prawdopodobnym jest również, aby toruński historyk sztuki znając jedną z dwóch poznańskich kolekcji nie wspomniał o fotografiach dotyczących Strzelna. Tymczasem autor zupełnie o tych zdjęciach nie informował. Sprawę częściowo i tylko w odniesieniu do Inowrocławia wyjaśnia wcześniejsza praca J. Frycza z 1975 roku. W tekście tym bowiem toruński historyk sztuki zamieścił reprodukcję kolejnej fotografii Meydenlendera, przedstawiającej kościół pw. NMP w ujściu od północnego-zachodu ${ }^{28}$. Tym razem naukowiec podał datę roczną 1888 , jako czas wykonania fotografii ${ }^{29}$. Jest to więc pierwsza nieścisłość w stosunku do późniejszej pracy tego samego autora z 1982 roku. Drugą taką niedokładność znajdujemy w opisie fotografii. Mianowicie, J. Frycz zawarł w nim informację z której wynika, iż zdjęcie wykonał Roman Stefan Ulatowski ${ }^{30}$. Oczywiście, nie jest to możliwe ponieważ wymieniony wyżej poznański fotograf urodził się w 1880 roku $^{31}$. Byłoby więc absurdem twierdzenie, iż ośmioletni chłopiec wykonywał zdjęcia w technice fotogrametrii. J. Frycz w opisie omawianej fotografii nie podał także zbioru czy miejsca, w którym miała się ona

${ }^{27}$ Frycz, Architektura i sztuka, s. przyp. 24 s. 430. J. Frycz informował o fotografiach ruiny kościoła pw. NMP w Inowrocławiu mających znajdować się w Bibliotece Uniwersyteckiej, ale z tekstu nie wynika czy miał okazję się z nimi zapoznać. Autor jednocześnie podał liczbę 5 fotografii, mających stanowić zbiór Kazimierza Ulatowskiego (do kwestii przynależności tej kolekcji jeszcze powrócę w dalszej części tekstu, por. przyp. 32). Właśnie te zdjęcia według J. Frycza mogły trafić z archiwum Miejskiego Konserwatora Zabytków w Poznaniu, gdzie przez pewien czas znajdowały się, do Biblioteki Uniwersyteckiej. Nie można jednak zgodzić się z tym poglądem z dwóch powodów. Po pierwsze fotografie Meydenlendera będące w zbiorach Biblioteki Uniwersyteckiej to aż 6 zdjęć a nie 5. Po drugie zbiór fotografii znajdujący się obecnie w Bibliotece Uniwersyteckiej trafił tam z dawnej Kaiser-Wilhelm-Bibliothek. Co zresztą zrozumiałe, gdyż Biblioteka Uniwersytecka przejęła zbiory, jak i budynek dawnej Biblioteki Cesarza Wilhelma. Por. przyp. 22, 23; Mrugalska-Banaszak, Jeden dzień z Ratuszem. Nie wydaje się aby obecnie znajdujący się w Bibliotece Uniwersyteckiej zbiór fotografii z 1887 roku był tożsamy z tym mającym należeć do Kazimierza Ulatowskiego. Niewykluczone, że ten ostatni bezpowrotnie zaginął. W kwestii bliższych informacji na temat K. Ulatowskiego wybitnego architekta i cenionego naukowca odsyłam do literatury, zob. K. Przybyszewski, Kazimierz Ulatowski (1884-1975), w: Wybitni ludzie dawnego Torunia, Warszawa 1982, s. 293-299.

${ }^{28}$ Frycz, Restauracja i konserwacja zabytków architektury w Polsce w latach 1795-1918, Warszawa 1975, s. 256. Por. PIOZS BUPń, nr 520. Spieszę dodać, że w 2011 nie znałem przywołanego wyżej tekstu J. Frycza. Stąd informowałem, iż naukowiec ten najprawdopodobniej nie znał fotografii oznaczonej numerem 520 .

${ }^{29}$ Frycz, Restauracja i konserwacja, s. 256.

${ }^{30}$ Tamże, s. 342.

${ }^{31}$ H. Kondziela, Roman Stefan Ulatowski, Poznań 1964, s. 8. 
znajdować ${ }^{32}$. Rozważania toruńskiego historyka sztuki, nie stały się przez długie lata inspiracją dla kolejnych uczonych. Naukowcy zajmujący się szczegółowo kościołem pw. NMP w Inowrocławiu, nie prowadzili poszukiwań materiału fotograficznego, o którym informował J. Frycz. W kolejnych opracowaniach, gdzie podejmowano się tematyki omawianej świątyni lub tamtejszych reliefów ze ścian romańskiej budowli, nie zwrócono uwagi na dziewiętnastowieczne fotografie ${ }^{33}$. Fakt ten tym bardziej dziwi, ponieważ analizowano głównie symbolikę reliefów, a przecież dla tej problematyki pierwotny układ ciosów z wyobrażeniami był bardzo ważny. Fotografie Meydenlendera prezentujące kościół przed jego renowacją powinny więc mieć kluczowe znaczenie dla takich rozważań. Dopiero w 2011 roku, uznając za w pełni wiarygodna informację J. Frycza o kolejnym materiale fotograficznym, który powinien znajdować się w Poznaniu, podjąłem się jego poszukiwań. Udało mi się poznać zbiór fotografii Meydenlendera, zgromadzony w Pracowni Ikonograficznej Oddziału Zbiorów Specjalnych Biblioteki Uniwersyteckiej. Następnie zaś dowiedziałem się o zdjęciach radcy rejencyjnego znajdujących się w Muzeum Historii Miasta Poznania ${ }^{34}$. Konsekwencją dotarcia do tych zbiorów było opublikowanie kolejnych dwóch dziewiętnastowiecznych fotografii kościoła pw. NMP w Inowrocławiu ${ }^{35}$. Tym sposobem od 2011 roku cały zestaw

${ }^{32}$ Frycz, Restauracja i konserwacja, s. 342. Mogę jedynie domniemywać, że omawiana fotografia znajdowała się w zbiorze, który J. Frycz przypisywał w 1982 roku K. Ulatowskiemu. Por. przyp. 27. W tym przypadku przynajmniej liczba zdjęć byłaby prawidłowa. J. Frycz informował bowiem o 5 fotografiach, które miał posiadać K. Ulatowski. Jednocześnie w publikacjach z 1975 i 1982 zamieścił on w sumie reprodukcje 5 fotografii Meydenlendera. Por. przyp. 26, gdzie kolejną fotografię z pracy J. Frycza, Architektura i sztuka, ryc. 10 s. 428, uznałem za wykadrowane zdjęcie prezbiterium kościoła pw. NMP. Por. PIOZS BUPń, nr 524. W związku z tym uważam, że toruński historyk sztuki znał tylko 5 fotografii Meydenlendera. Sporna zaś pozostaje kwestia tego, który z Ulatowskich posiadał zdjęcia, stanowiące prawdopodobnie podstawę dla późniejszych rozważań J. Frycza. Henryk Kondziela informował bowiem, iż w archiwum Miejskiego Konserwatora Zabytków w Poznaniu znajdowała się kolekcja negatywów R.S. Ulatowskiego, zob. Kondziela, Roman Stefan Ulatowski, s. 15.

${ }^{33}$ Sikorski, Kościót Imienia, s. 3-37; tenże Reliefy z murów, s. 17-34; Tenże, Kościót p.w. Imienia Najświętszej Marii Panny w Inowrocławiu, „Rocznik Kasprowiczowski”, 9 (2000) s. 137-141; Sroka, Zagrożenia i lęki, s. 106-120; K. Hewner, Funkcja rzeźb i rytów na murach romańskiego kościoła pw. Imienia NMP w Inowrocławiu, „Ziemia Kujawska”, 17 (2004) s. 213-217. Wyjątkiem na tym tle jest tekst Andrzeja Szymkowskiego, w którym znalazła się jedna fotografia Meydenlendera przedstawiająca kościół w ujęciu od strony południowo-zachodniej, zob. A. Szymkowski, Problemy konserwacji zabytków architektury romańskiej kręgu kujawsko-wielkopolskiego, „Zapiski Kujawsko-Dobrzyńskie. Seria C. Oświata i Kultura" (1980), s. 71. Por. PIOZS BUPń, nr 519. Niestety, A. Szymkowski uznał błędnie, że fotografia ta ilustruje ruinę inowrocławskiego kościoła po pierwszej wojnie światowej.

${ }^{34}$ Nieocenioną pomoc w odszukaniu fotografii Meydenlendera z Biblioteki Uniwersyteckiej udzielił mi J. Skutecki, który również poinformował mnie o kolekcji zdjęć z Muzeum Miasta Poznania.

${ }^{35}$ Danielewski, Reliefy z murów, s. 9. Por. PIOZS BUPń, nr 520, 521. Zamieszczone przeze mnie w wyżej wymienionej publikacji fotografie Meydenlendera, również są wykadrowane. Było to związane z wymaganiami redakcji. 
zdjęć autorstwa Meydenlendera, a dotyczący omawianego inowrocławskiego zabytku jest znany, choć opublikowany w trzech osobnych pracach ${ }^{36}$.

Zupełnie inaczej wygląda sytuacja $\mathrm{z}$ fotografiami przedstawiającymi rotundę pw. Św. Krzyża oraz zabudowania kościoła pw. Św. Trójcy i NMP w Strzelnie, które wykonał radca rejencyjny. W przypadku tych zabytków znajomość omawianych zdjęć w literaturze przedmiotu była znikoma. W zasadzie tylko w pracy Jerzego Kozłowskiego znalazła się jedna $\mathrm{z}$ fotografii Meydenlendera, przedstawiająca rotundę pw. Św. Krzyża. Z tym że historyk ten nie znał datacji rocznej tego zdjęcia oraz jego autora ${ }^{37}$. Fakt ten akurat nieco dziwi, ponieważ na przywołanej fotografii widnieje zegar znajdujący się wówczas na rotundzie $\mathrm{i}$ jest tam wyraźna data roczna $1887^{38}$. Podsumowując trzeba zauważyć, iż fotografie przedstawiające w 1887 roku zabytki architektury romańskiej Strzelna, były w dotychczasowej literaturze przedmiotu prawie nieznane ${ }^{39}$.

Przechodząc do szczegółowego omówienia materiału fotograficznego należy podkreślić, że kolejne zdjęcia Meydenlendera, mam w tym przypadku na uwadze te z kolekcji Pracowni Ikonograficznej Oddziału Zbiorów Specjalnych Biblioteki Uniwersyteckiej, gdyż z nich pochodzą skany zamieszczone w tymże tekście, mają własną numerację. Zestaw zdjęć odnoszących się do inowrocławskiego kościoła pw. NMP posiada numery od 519 do 524 . Podczas gdy fotografiom zabytków romańskich ze Strzelna nadano numery od 526 do 534. Wśród tych zdjęć należy szczególną uwagę zwrócić na te oznaczone cyframi 530 i 531. Fotografie te bowiem ilustrują stan zachowania klasztoru w jego części północno-wschodniej. Nie mogą to jednak być zdjęcia z tego samego czasu. Na fotografii o numerze 530 w miejscu zniszczonej wieży północnej tuż przy transepcie ${ }^{40}$, znajduje się duża ilość gruzu, której brakuje na zdjęciu o numerze 531. Drugi element wskazujący

${ }^{36}$ Frycz, Restauracja i konserwacja, s. 256; tenże, Architektura $i$ sztuka, ryc. 7 s. 425 , ryc. 8 s. 426, ryc. 9 s. 427 , ryc. 16 s. 442; Danielewski, Reliefy z murów, s. 9.

${ }^{37}$ J. Kozłowski, Strzelno pod pruskimi rzadami (1815-1918), Strzelno 2005, ryc. 4. W przypadku tej fotografii również ona została wykadrowana. Dodać trzeba, że o dziewiętnastowiecznych fotografiach klasztoru norbertanek informował również Aleksander Holas. Autor uznał, iż zdjęcia ilustrujące ruinę wspomnianego wyżej zabytku, pochodzą z około 1890 roku, zob. A. Holas, Architektura kościoła św. Prokopa w Strzelnie, w: Strzelno romańskie. Zbiór studiów, Strzelno 1972, s. 30. Niestety naukowiec ten nie zamieścił w tekście reprodukcji tych fotografii. Trudno więc jednoznacznie stwierdzić czy A. Holas informując o dziewiętnastowiecznych zdjęciach, miał na uwadze materiał fotograficzny Meydenlendera.

${ }^{38}$ Por. PIOZS BUPń, nr 527. Oczywiście, brak informacji w pracy J. Kozłowskiego na temat autora fotografii jest już bardziej uzasadniony.

${ }^{39}$ Krótką notę informacyjną na temat tych fotografii autorstwa Meydenlendera zamieściłem w tekście z 2011 roku, zob. Danielewski, Reliefy z murów, przyp. 30 s. 19. Natomiast, nie publikowałem tam zdjęć zabytków architektury romańskiej Strzelna, gdyż praca ta nie dotyczyła średniowiecznych świątyń z tejże miejscowości. W poszukiwaniu publikacji, gdzie mogłyby znaleźć się reprodukcje fotografii Meydenlendera nieocenioną pomocą służył mi Jacek Sech z Koła Polskiego Towarzystwa Historycznego w Strzelnie.

${ }^{40} \mathrm{~W}$ tym miejscu przy północnej części transeptu znajdują się obecnie pozostałości rekonstrukcji romańskiej wieży, zob. Sulkowska-Tuszyńska, Klasztor norbertanek, ryc. 32, s. 46; Świechowski, Katalog architektury, s. 467. 
na fakt, iż nie jest to materiał fotograficzny $\mathrm{z}$ tego samego czasu, wydaje się jeszcze bardziej znaczący. W tym przypadku uwagę trzeba zwrócić na budynek klasztorny, który przylega prostopadle do świątyni już na wysokości północnej ściany transeptu. Mianowicie, do tej południowej części zachodniego skrzydła klasztornego na fotografii o numerze 531 prowadzi wejście od strony wschodniej. Tymczasem na zdjęciu o numerze 530 ten element jest zamurowany ${ }^{41}$. Nie możliwe więc aby Meydenlender wykonał obie fotografie w tym samym okresie. Wyjaśnienie tej kwestii nasuwa wiele wątpliwości. Fotografie zostały wykonane tą samą techniką, wówczas jeszcze niezbyt powszechną w użyciu, ich wielkość jest identyczna i znajdują się one w zbiorach dwóch poznańskich instytucji, gdzie uważane są za zestaw zdjęć tego samego autora. Jak więc racjonalnie thumaczyć niezgodność obu zdjęć? Można uznać, iż osobą która zrobiła jedno z tych zdjęć, jest ktoś inny niż Meydenlender. Trudno jednak wówczas byłoby wyjaśnić cechy wspólne łączące te fotografie czyli technikę ich wykonania i rozmiary. Jednocześnie samo fotografowanie w XIX wieku zabytków na ziemiach polskich nie było raczej powszechnym zjawiskiem. Zrobienie zdjęcia wymagało sprzętu i dużych umiejętności. Wszystko to więc pośrednio przemawia za Meydenlenderem, jako autorem obu fotografii. Uznając jednak radcę rejencyjnego za osobę, która wykonała oba zdjęcia należałoby stwierdzić, iż był on dwukrotnie w Strzelnie. W tym miejscu trzeba dodać, że mamy jeszcze jedno zdjęcie, tym razem przedstawiające rotundę pw. Św. Krzyża, które nie pasuje do pozostałego materiału fotograficznego, przedstawiającego ten zabytek. Mianowicie, na fotografii o numerze 532 brakuje dużej ilości gruzu ${ }^{42}$. Podczas gdy na pozostałych zdjęciach $\mathrm{z}$ omawianego zbioru ilustrujących rotundę, ten gruz znajduje się na południowy-zachód od wieży romańskiego zabytku ${ }^{43}$. Wydaje się więc, że również zdjęcie o numerze 532 pod względem jedności stanu zachowania i wyglądu kolejnych miejsc związanych $\mathrm{z}$ architekturą Strzelna, nie pasuje do reszty materiału fotograficznego. Sądzę więc, iż dwie z trzech omawianych fotografii o numerach 530, 531, 532 są z innego okresu niż pozostałe zdjęcia ${ }^{44}$. Możliwe wobec tego, że Meydenlender był ponownie w Strzelnie lub też wizytował je przed 1887 rokiem, czyniąc rekonesans przed finalnym etapem podroży i to wówczas te dwa zdjęcia wykonał. Z braku jednak jednoznacznych przesłanek nie podejmuję się ostatecznego rozwiązania kwestii tego czy radca rejencyjny przebywał w Strzelnie przed 1887 rokiem, czy też może po tej dacie ${ }^{45}$.

${ }^{41}$ PIOZS BUPń, nr 530, 531.
${ }^{42}$ PIOZS BUPń, nr 532.
${ }^{43}$ PIOZS BUPń, nr 527, 528, 529.
${ }^{44}$ PIOZS BUPń, nr 530, 531, 532.
${ }^{45}$ Na uboczu jednak chcę zauważyć, że w 1999 roku wejście to było nadal zamurowane, zob. Sulkowska-Tuszyńska, Klasztor norbertanek, ryc. 165. Fakt ten może sugerować, że po jego zamurowaniu w XIX wieku wejście nie pełniło już swojej funkcji. Wówczas należałoby uznać, iż fotografia o numerze 531 (wraz z nią 532) powstała przed resztą omawianego materiału fotograficznego wykonanego w sierpniu 1887 roku, gdyż tylko wtedy wejście istniało i mogło zostać uchwycone na zdjęciu. Wyjaśnienie to jednak nie jest satysfakcjonujące. Zwłaszcza, że omawiany element budyn- 
Poniżej przedstawiam dokładny opis wszystkich fotografii autorstwa Meydenlendera, ilustrujących romańskie zabytki architektury sakralnej Inowrocławia oraz Strzelna. Jednocześnie do opisów załączam również skany omawianych zdjęć z 1887 roku, które są zgromadzone w Pracowni Ikonograficznej Oddziału Zbiorów Specjalnych Biblioteki Uniwersyteckiej w Poznaniu. Sądzę że zarówno dla naukowców zajmujących się problematyką romańskiej architektury Inowrocławia oraz Strzelna, jak i dla władz konserwatorskich, omawiane fotografie Meydenlendera powinny stanowić ważne zaplecze źródłowe. Materiał fotograficzny ilustruje bowiem dziewiętnastowieczny obraz zabytków nieruchomych, które to wówczas w porównaniu do okresu średniowiecza były w znacznym stopniu przebudowane. Jednocześnie zdjęcia radcy rejencyjnego wyraźnie pokazują stan zachowania architektury sakralnej Inowrocławia i Strzelna w latach 80. XIX wieku. W przypadku Strzelna bardzo interesująca wydaje się część budynków klasztornych obecnie nieistniejąca, a uwieczniona na fotografiach. Meydenlender wykonując zdjęcia zachował dziewiętnastowieczny obraz tych unikalnych zabytków i trudno nie dostrzec samej roli tego na wpół anonimowego fotografa, jak i rangi tychże źródeł, względem architektury Inowrocławia oraz Strzelna.

\section{Inowroclaw}

Fotografia o numerze 519 przedstawia widok kościoła pw. NMP od strony południowo-zachodniej. Szczególnie dobrze widoczna jest na niej część wieżowa świątyni wraz z portalem zachodnim. W systemie wieżowym widoczne są liczne ślady mocowań na rusztowania (w postaci małych zwykle czworokątnych otworów) ${ }^{46}$, obecnie zamurowanych. Podobnie w wieżach rejestrujemy zamurowane otwory okienne. Fotografia dobrze również ilustruje pęknięcie biegnące przez środek północnej wieży i od tejże strony. Na zdjęciu widoczna jest także częściowo ściana południowa kościoła $\mathrm{z}$ tamtejszym wejściem do świątyni ${ }^{47}$.

Fotografia o numerze 520 prezentuje kościół pw. NMP w ujęciu od strony północno-zachodniej. W ten sposób na głównym planie znajduje się część wieżowa świątyni z portalem zachodnim. W tym przypadku zauważalne są również dwa pęknięcia wieży północnej. Na zdjęciu widoczna jest także ściana północna z tamtejszym portalem i niektórymi z reliefów. W systemie wieżowym zauważalne są także ślady mocowania rusztowań oraz zamurowane otwory okienne ${ }^{48}$.

Fotografia o numerze 521 ilustruje przede wszystkim ścianę północną inowrocławskiego kościoła z licznymi reliefami w niej umiejscowionymi. Oprócz tego ponownie widoczny jest system wieżowy ze śladami po mocowaniu rusztowań $i$ zamurowanymi otworami okiennymi. Szczególnie warte zauważenia są kolejne

\footnotetext{
ku klasztornego w przeciągu okresu między 1887 a 1999 rokiem mógł być kilkukrotnie zamurowywany i ponownie przebijany.

${ }^{46}$ Informując dalej o śladach mocowania rusztowań nie będę każdorazowo pisał, że są one zauważalne na fotografiach inowrocławskiego kościoła pw. NMP w postaci otworów.

${ }^{47}$ PIOZS BUPń, nr 519.

${ }^{48}$ PIOZS BUPń, nr 520.
} 
pęknięcia w wieży północnej obserwowalne zarówno od strony północnej, jak i wschodniej. Na zdjęciu widoczna jest również północna ściana prezbiterium ${ }^{49}$. Obecnie w tym miejscu znajduje się półkolista apsyda ${ }^{50}$.

Fotografia o numerze 522 ilustruje przede wszystkim południową ścianę kościoła pw. NMP z wejściem do jego wnętrza od tejże strony. Na zdjęciu widoczna jest również wieża południowa ze śladami mocowania rusztowań i zamurowanymi otworami okiennymi. Jeden $\mathrm{z}$ takich zamurowanych otworów rejestrujemy także w ścianie południowej. Warto dodać, że wschodnia część południowej ściany została na fotografii słabo uchwycona ${ }^{51}$.

Fotografia o numerze 523 ilustruje emporę kościoła oraz wieże widziane od wewnątrz budowli. $\mathrm{W}$ tym przypadku $\mathrm{w}$ ścianach wież ponownie widoczne są ślady mocowania rusztowań oraz zamurowane niektóre otwory okienne. Wschodnia ściana wieży północnej nosi ślad pęknięcia. Mniejsze szczeliny widoczne są także nad emporą oraz w ścianie wieży południowej. Zdjęcie ilustruje również częściowy wygląd ściany północnej i południowej ${ }^{52}$.

Fotografia o numerze 524 przedstawia widok prezbiterium kościoła pw. NMP od wewnątrz budowli. Na zdjęciu uchwycono również częściowo ścianę północną i południową kościoła ${ }^{53}$.

\section{Strzelno}

Fotografia o numerze 526 przedstawia prezbiterium rotundy pw. Św. Krzyża od strony południowo-wschodniej. Na zdjęciu od południa do prezbiterium przylega nieistniejący już jeden z budynków klasztornych. Fotografia ilustruje również częściowo zwieńczenie podkowiastej wieży rotundy. Warto dodać, iż zdjęcie wschodniej ściany prezbiterium wskazuje, że niższy z otworów okiennych był wówczas zamurowany. Jednocześnie ta część rotundy była w XIX wieku znacznie wyższa niż współcześnie ${ }^{54}$.

Fotografia o numerze 527 przedstawia rotundę pw. Św. Krzyża oraz inne zabudowania, znajdujące się wówczas $\mathrm{w}$ jej otoczeniu. W zasadzie $\mathrm{z}$ rotundy na zdjęciu uchwycona została podkowiasta wieża oraz część nawy. Budowlę ujęto na fotografii od strony południowo-zachodniej. Na przedzie wieży umiejscowiony jest zegar, na którym widnieje data roczna 1887 oraz godzina, około 11.00. Warto także zwrócić uwagę na przebite w murze wieży wejście do jej wnętrza, umiejscowione tuż obok przypory ${ }^{55}$.

\footnotetext{
${ }^{49}$ PIOZS BUṔ́, nr 521.

${ }^{50}$ Fundamenty apsydy odkrył Julius Kohte w 1891 roku, zob. Frycz, Architektura i sztuka, s. 426.

${ }^{51}$ PIOZS BUPń, nr 522.

${ }^{52}$ PIOZS BUPń, nr 523.

${ }^{53}$ PIOZS BUPń, nr 524.

${ }^{54}$ PIOZS BUPń, nr 526.

${ }^{55}$ PIOZS BUPń, nr 527.
} 
Fotografia o numerze 528 również ilustruje rotundę pw. Św. Krzyża. Tym razem na zdjęciu uchwycono stan zachowania wieży oraz nawy od strony zachodniej. Na fotografii znalazły się również inne okoliczne zabudowania. Ponownie widoczny jest zegar z datą roczną 1887, który wskazuje godzinę około 11.30. Najciekawszym elementem całej fotografii wydaje się przybudówka przylegająca od północy do nawy. W ścianie zachodniej tego dobudowanego do rotundy budynku widzimy tympanon fundacyjny rotundy pw. Św. Krzyża, który w 1945 roku uległ zniszczeniu ${ }^{56}$. Trzeba dodać, że fotografia dzięki jakości wykonania bardzo wyraźnie ilustruje tympanon, co pozwala rozróżnić zarys wszystkich znajdujących się na nim postaci ${ }^{57}$.

Fotografia o numerze 529 także przedstawia rotundę pw. Św. Krzyża. Tym razem na zdjęciu uchwycono podkowiastą wieżę bez jej zwieńczenia oraz nawę od strony północno-zachodniej. Na fotografii widoczne są również częściowo inne okoliczne budynki w tym kościół pw. Św. Trójcy i NMP. Tym razem data na zegarze oraz czas są nieczytelne. Zdjęcie potwierdza również fakt, iż w momencie jego wykonania w miejscu, w którym obecnie znajduje się apsyda zlokalizowana bliżej wieży, nie było tego elementu rotundy. Natomiast, zza schodów prowadzących do jednej z przybudówek łączących się z nawą, widoczna jest wnęka i krata. Jest to najprawdopodobniej wejście od apsydki prowadzące do niej od wewnątrz rotundy. Swiadczy to o tym, że apsyda ta była wówczas zniszczona. Co zresztą potwierdzają słabo widoczne ruiny tego elementu rotundy. Innym elementem wartym odnotowania jest wejście do wieży (obecnie nieistniejące) prowadzące od strony północno-zachodniej ${ }^{58}$.

Fotografia o numerze 530 przedstawia północno-wschodnią część kościoła pw. Św. Trójcy i NMP. Na zdjęciu widoczne jest od strony północnej prezbiterium $\mathrm{z}$ apsydą oraz transept. Od wschodu do transeptu przylegają zabudowania klasztorne. Na fotografii w miejscu współcześnie częściowo odbudowanej wieży ${ }^{59}$, znajduje się wysoka warstwa gruzu ${ }^{60}$.

Fotografia o numerze 531 ilustruje północno-wschodnią część kościoła pw. Św. Trójcy i NMP. Zdjęcie to jest jednak zrobione w większym oddaleniu od budynków niż omawiana wyżej fotografia o numerze $530^{61}$.

Fotografia o numerze 532 przedstawia widok rotundy pw. Św. Krzyża. Zdjęcie zrobiono od strony północno-zachodniej i uchwycono na nim podkowiastą wieżę bez jej zwieńczenia oraz nawę. Dodatkowo na fotografii widoczny jest częściowo kościół pw. Św. Trójcy i NMP oraz inne zabudowania klasztorne. Ponow-

${ }^{56}$ Świechowski, Katalog architektury, s. 489. Por. przyp. 20. Wymieniony naukowiec informował również o tym, że omawiany tympanon przed renowacją rotundy w 1892 roku znajdował się w ścianie jednej z przybudówek, z tym że była to wtórna lokalizacja tego zabytku. Przywołana fotografia w zupełności potwierdza spostrzeżenia Z. Świechowskiego.

${ }^{57}$ PIOZS BUPń, nr 528.

${ }^{58}$ PIOZS BUPń, nr 529.

${ }^{59}$ Patrz przyp. 40.

${ }^{60}$ PIOZS BUPń, nr 530.

${ }^{61}$ PIOZS BUPń, nr 531. Por. uwagi porównawcze czynione wcześniej a odnoszące się do fotografii o numerach 531 i 530 . 
nie szczególnie interesujący wydaje się budynek przylegający od północy do nawy rotundy. Na zachodniej ścianie tej budowli widoczny jest wtórnie tam wstawiony tympanon fundacyjny ${ }^{62}$. Pod tym względem fotografia ta dobrze uzupełnia zdjęcie autorstwa Meydenlendera o numerze $528^{63}$.

Fotografia o numerze 533 przedstawia wnętrze kaplicy św. Barbary z wtórnie wstawioną $\mathrm{w}$ tym miejscu romańską kolumną, mającą podtrzymywać gotyckie sklepienie $^{64}$. W tle widoczne jest także wejście do kaplicy oraz ówczesne jej wyposażenie ${ }^{65}$.

Fotografia o numerze 534 prezentuje wnętrze rotundy pw. Św. Krzyża widziane od strony wejścia ku prezbiterium. W posadzce budynku zarejestrować można dziury, a samo wnętrze świątyni jest prawie zupełnie puste. Na ścianach prezbiterium widoczne są ślady malowideł. Jednocześnie wejście do jednej z apsydek na zdjęciu jest zamurowane ${ }^{66}$.

${ }^{62}$ PIOZS BUPń, nr 532. Por. przyp. 57.

${ }^{63}$ PIOZS BUPń, nr 528.

${ }^{64} \mathrm{Na}$ temat tej kolumny i jej wtórnego użycia odsyłam do następujących prac, zob. SulkowskaTuszyńska, Klasztor norbertanek, ryc. 145; Świechowski, Katalog architektury, s. 465.

${ }^{65}$ PIOZS BUPń, nr 533.

${ }^{66}$ PIOZS BUPń, nr 534. 




Fot. nr. 519. Kościół pw. NMP w Inowrocławiu. Widok od strony południowo-zachodniej.



Fot. nr. 520. Kościół pw. NMP w Inowrocławiu. Widok od strony północno-zachodniej. 


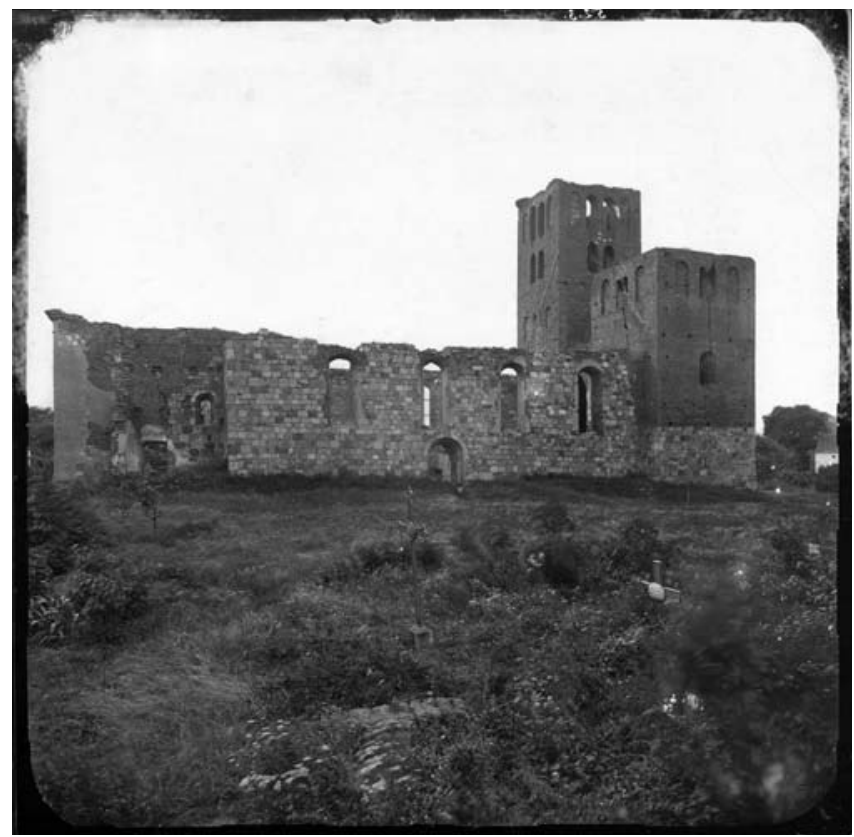

Fot. nr 521. Kościół pw. NMP w Inowrocławiu. Widok od strony północnej.



Fot. nr. 522. Kościół pw. NMP w Inowrocławiu. Widok od strony południowej. 


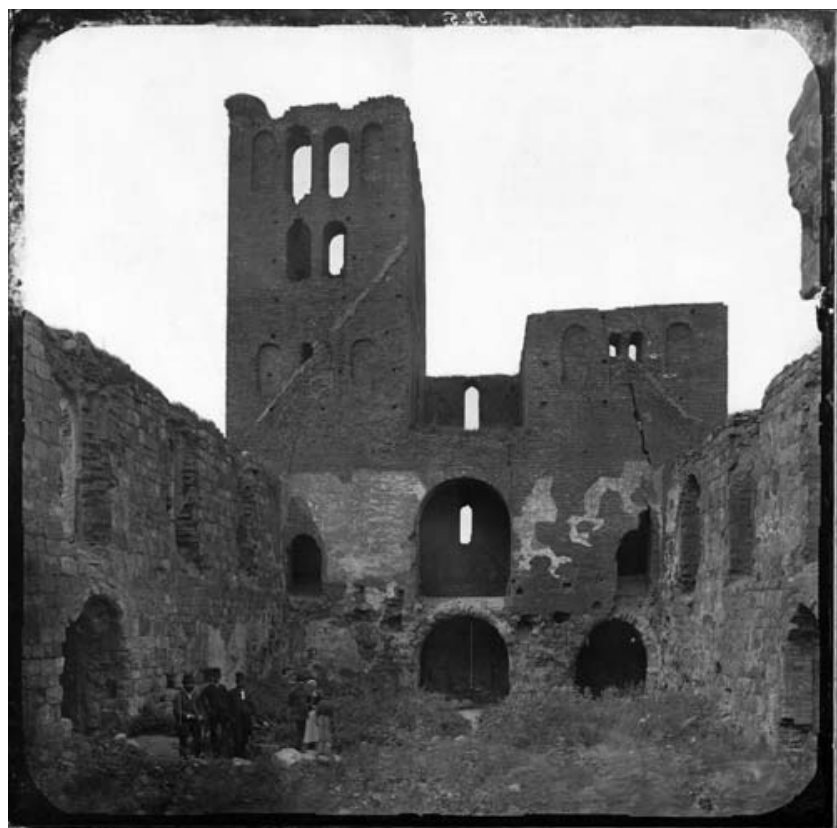

Fot. nr 523. Kościół pw. NMP w Inowrocławiu widok na emporę i wieże wykonany od wewnątrz budowli.

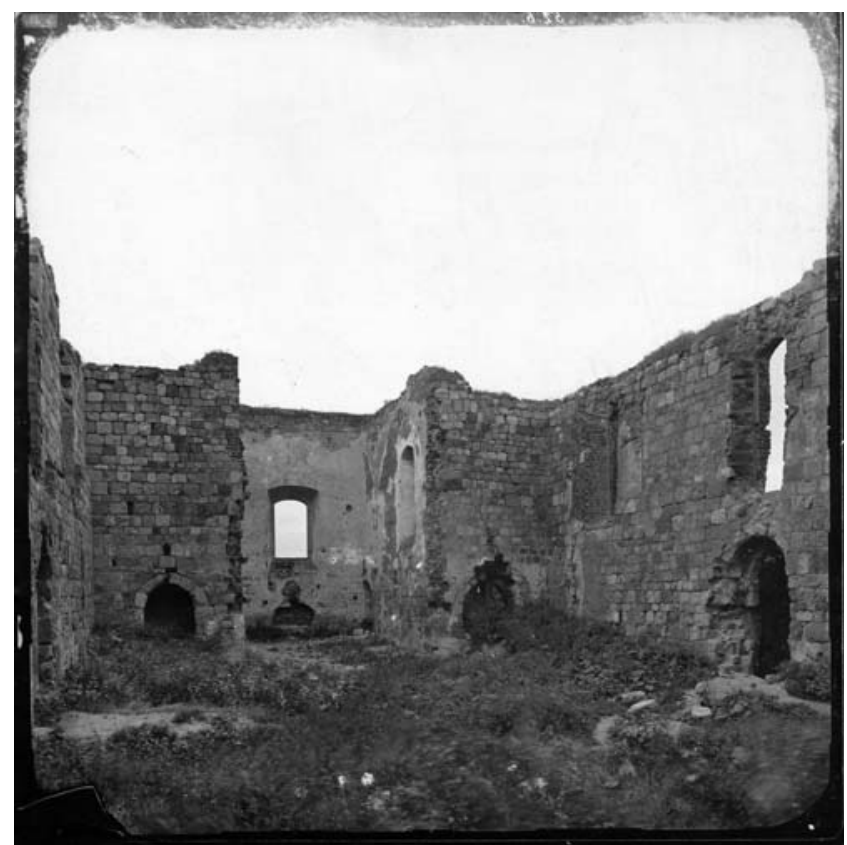

Fot. nr. 524. Kościół pw. NMP w Inowrocławiu widok na prezbiterium wykonany od wewnątrz budowli. 


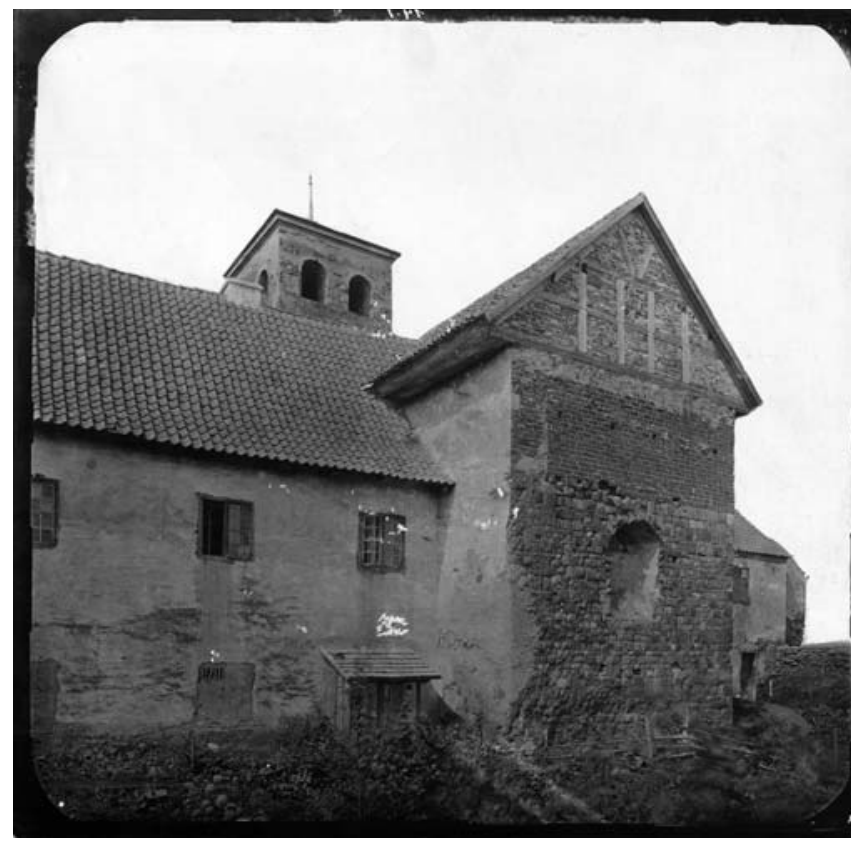

Fot. nr 526. Rotunda pw. Św. Krzyża w Strzelnie widok na prezbiterium.

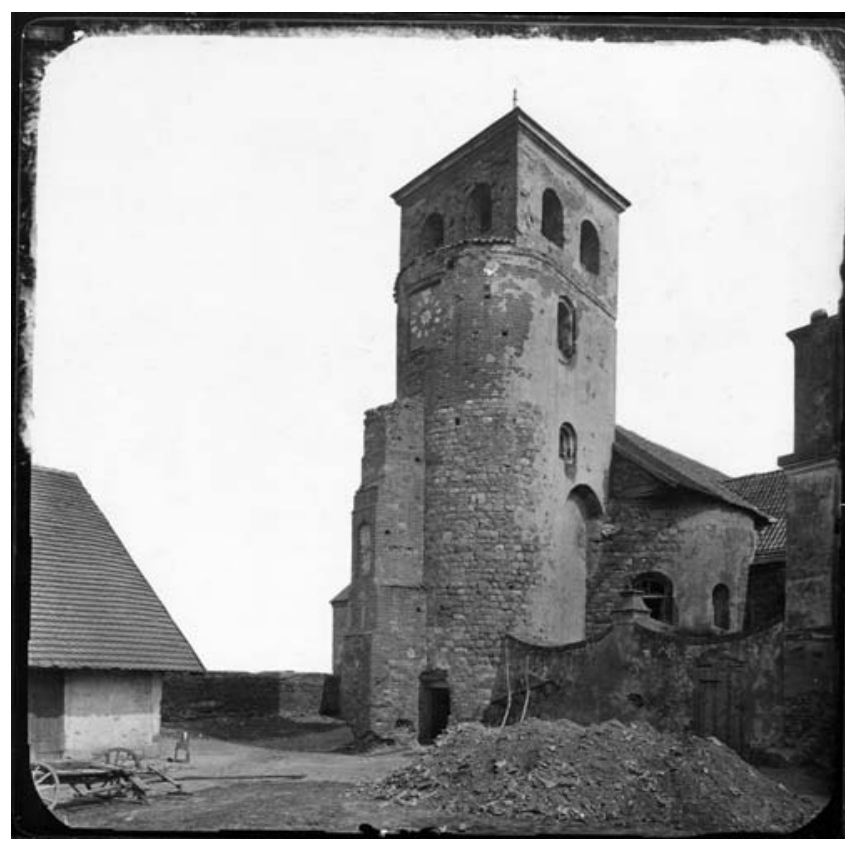

Fot. nr 527. Rotunda pw. Św. Krzyża w Strzelnie widok od strony południowo-zachodniej. 




Fot. nr 528. Rotunda pw. Św. Krzyża w Strzelnie widok od strony zachodniej.



Fot. nr 529. Rotunda pw. Św. Krzyża w Strzelnie widok od strony północno-zachodniej. 


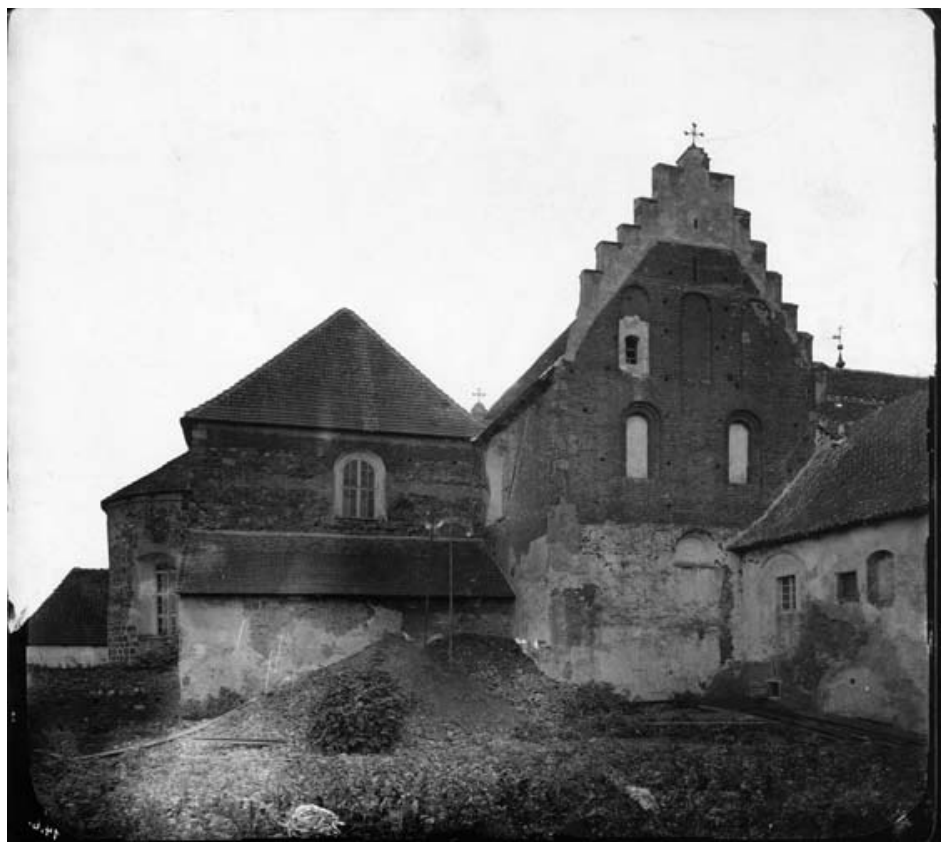

Fot. nr 530. Kościół pw. Świętej Trójcy i NMP w Strzelnie widok od strony północno-wschodniej.

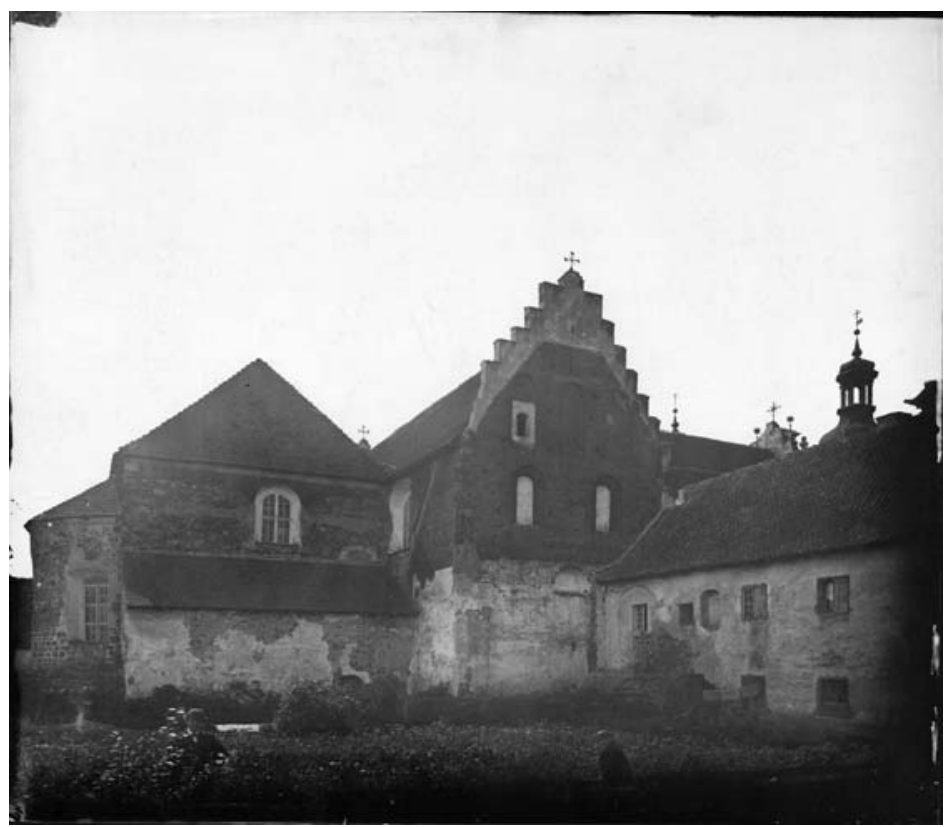

Fot. nr 531. Kościół pw. Św. Trójcy i NMP w Strzelnie widok od strony północno-wschodniej. 


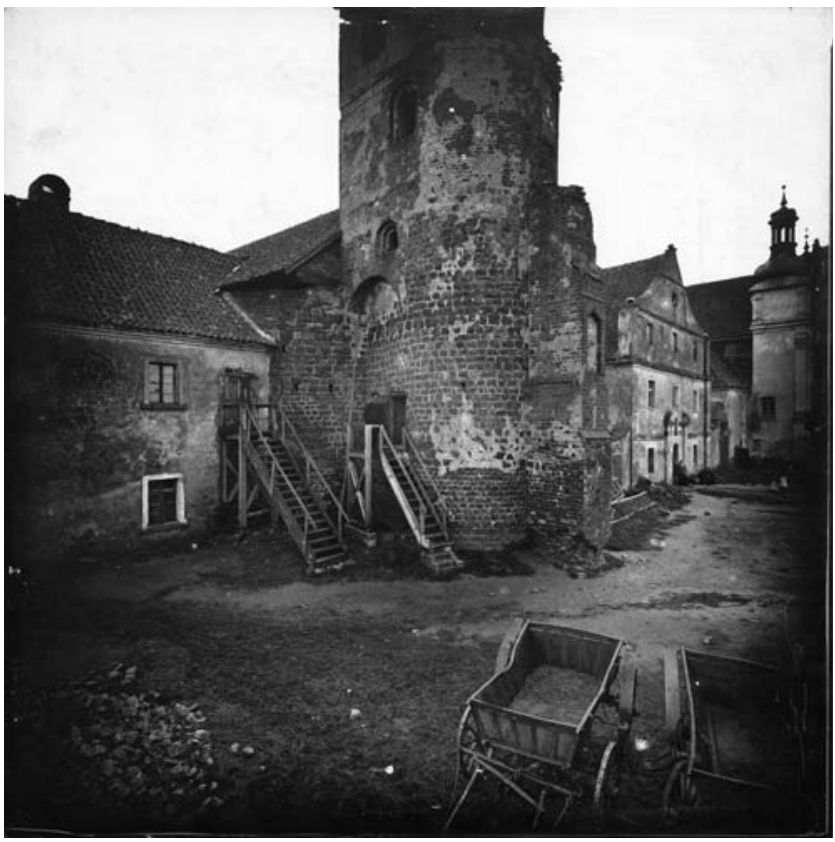

Fot. nr 532. Rotunda pw. Św. Krzyża w Strzelnie widok od strony północno-zachodniej.

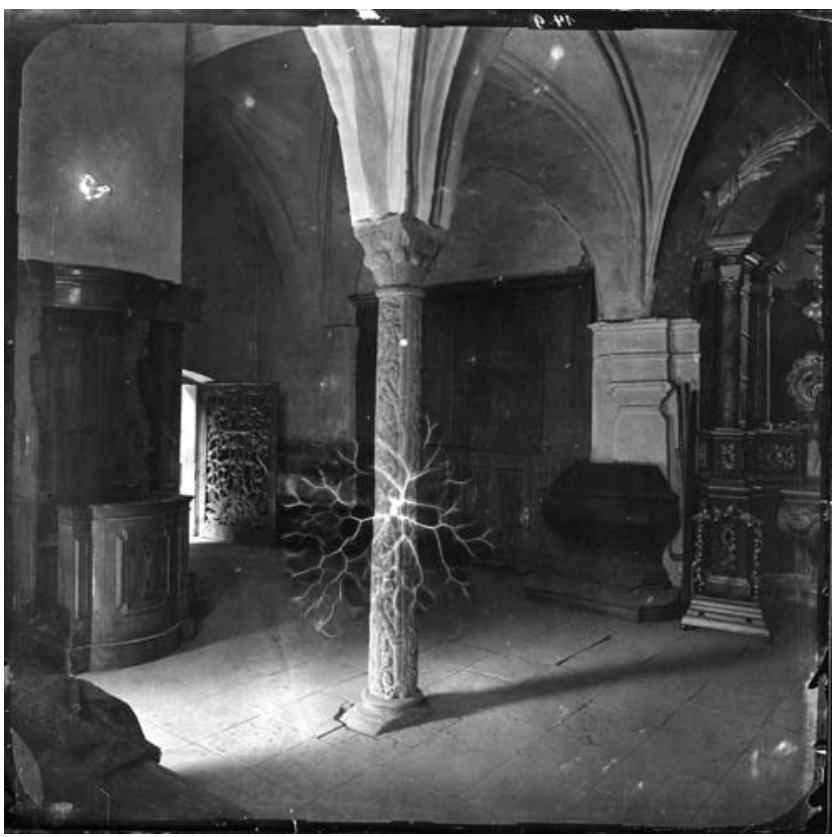

Fot. nr 533. Wnętrze kaplicy św. Barbary w Strzelnie. 


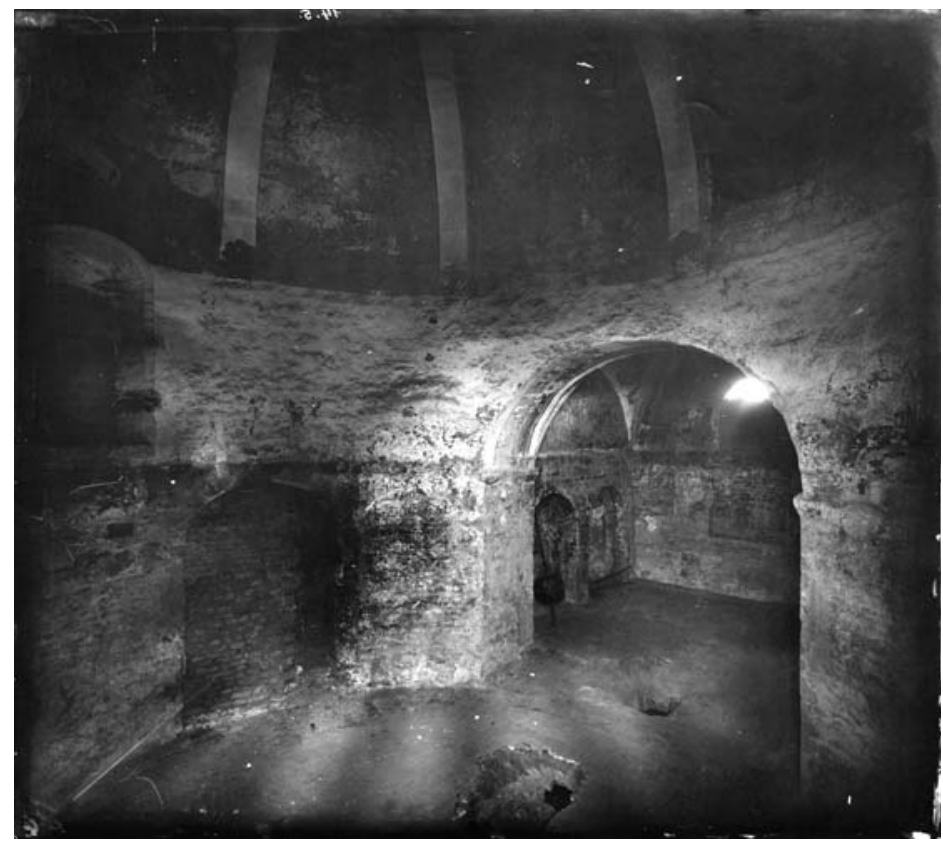

Fot. nr 534. Wnętrze rotundy pw. Św. Krzyża w Strzelnie. 


\title{
ROMANESQUE MONUMENTS OF RELIGIOUS ARCHITECTURE IN STRZELNO AND INOWROCŁAW IN THE LIGHT OF MEYDENLENDER'S PHOTOGRAPHY OF 1887
}

\begin{abstract}
Summary
The article concerns a collection of the nineteenth-century photography, which is located in the Iconographic Studio of the Special Collections Department in University Library of Poznan. These unique photos of 1887 were taken by Meydenlender. In addition, some of Meydenlender's photo prints are in the collections of the Museum of the City of Poznań. The primary objective of the text was to present the collection of photographs depicting Romanesque architecture of Strzelno and Inowrocław. The photographs show the condition of the Church dedicated to the Blessed Virgin Mary in Inowrocław, the Saint Cross's Rotunda of Strzelno and the Church dedicated to St. Trinity and the Blessed Virgin Mary. They are also a valuable source in terms of conservation. In order to introduce a little-known collection of photographic material, the author examined a number of issues directly connected with them. The text touches upon the person of Meydenlender, as well as the issue of when and in what order the photographs of monuments in Strzelno and Inowrocław were taken. There is also information about what happened to the photographic material gathered in two collections. It was possible to determine that after being taken, the two sets of photographs were in different institutions and repeatedly changed their locations. One of the collections was in Berlin in 1906. However, it was impossible to determine what happened to the photographs right after they were taken. Both collections of photographic material were compared with each other. As a result the photographs were counted, and the photos whose authorship cannot be attributed to Meydenlender were selected from the collection of the Museum of the City of Poznan. The basis for further considerations are fifteen photos. Six of them showed the Church devoted to the Blessed Virgin Mary in Inowrocław and the other nine the Saint Cross's Rotunda of Strzelno, the Church dedicated to St. Trinity and the Blessed Virgin Mary, and other monastic buildings in Strzelno. Only some of the discussed photographs have been published so far, mainly those related to the church in Inowrocław. At the same time it was noted that usually when Meydenlender's photos were published, the name of the author was not given as he was unknown, and the date of the photos was not given correctly. Photographs are not homogeneous, it is possible that two of them were taken at a different time than the others. The article also indicates the high conservation value of the photos which depict the monuments of Strzelno and Inowrocław before the renovation (respectively in 1892 and the years 1900 to 1902). It is worth mentioning that the two photographs of the Saint Cross's Rotunda show the foundation tympanum destroyed in 1945, which was set in the outer wall of one of the buildings in 1887. The photos show the terrible condition of the monuments of Strzelno, as well as how their nineteenth-century appearance differed from Romanesque mass of the both buildings. It is also worth noting that a detailed analysis of two photographs of the rotunda made it possible to determine the exact time at which they were taken. The photos of the Church dedicated to the Blessed Virgin Mary in Inowrocław allowed to point out extensive damage in the walls of the church. At the same time photographic material was a good source to indicate the changes made in the course of reconstruction in the years 1900-1902. The detailed analysis of the photos allowed to notice the fact that during renovation of the Church dedicated to the Blessed Virgin Mary the original traces of scaffold fasteners were bricked up. This study presented the photographic materials of high value in terms of sources, which had been previously largely unknown.
\end{abstract}

